Check for updates

Cite this: RSC Adv., 2017, 7, 48286

\title{
Graphene enhanced silicon/carbon composite as anode for high performance lithium-ion batteries
}

\author{
Xiaohui Li, (D) Mengqiang Wu, ${ }^{*}$ Tingting Feng, ${ }^{*}$ Ziqiang Xu, Jingang Qin, \\ Cheng Chen, (D) Chengyang Tu and Dongxia Wang
}

Silicon-based anode materials for lithium ion batteries (LIBs) have become a hot research topic due to their remarkably high theoretical capacity $\left(4200 \mathrm{~mA} \mathrm{~h} \mathrm{~g}^{-1}\right)$. However, the large volume change (>300\%) of $\mathrm{Si}$ electrodes during the lithium ion insertion/extraction process leads to a rapid decay of the reversible capacity. In our report, carbon/graphene double-layer coated-silicon composite (Si/carbon/graphene, Si/ $\mathrm{C} / \mathrm{G}$ ) is prepared via a facile hydrothermal process. It is demonstrated that the $\mathrm{Si} / \mathrm{C} / \mathrm{G}$ composite displayed an exceedingly ameliorated electrochemical performance in both cycling stability and rate capability. The specific capacity of the Si/C/G electrode is maintained at $2469 \mathrm{~mA} \mathrm{~h} \mathrm{~g}^{-1}$ after 50 cycles under $0.2 \mathrm{~A} \mathrm{~g}^{-1}$, and above $1500 \mathrm{~mA} \mathrm{~h} \mathrm{~g}$ after 300 cycles at $2 \mathrm{~A} \mathrm{~g}^{-1}$. More notably, even at an ultrahigh rate of $32 \mathrm{~A} \mathrm{~g}^{-1}$, the specific capacity could still reach $471 \mathrm{~mA} \mathrm{~h} \mathrm{~g}^{-1}$. Hence the presented simple approach enables massive fabrication of the Si/C/G composite as a promising anode material for high performance LIBs.

Received 4th September 2017 Accepted 9th October 2017

DOI: 10.1039/c7ra09818a

rsc.li/rsc-advances conductivity of silicon and improve the overall electrochemical performance. Besides the high specific capacity, the rate capability of the electrode is also one of the most pivotal properties that should be examined, especially for high-power applications. ${ }^{11}$ There have been a few research studies which investigated the electrochemical properties of $\mathrm{Si}$ electrode at high charge/discharge rates. For instance, Wu et al. ${ }^{12}$ synthesized silicon oxide-coated Si tubes that can obtain $540 \mathrm{~mA} \mathrm{~h} \mathrm{~g}^{-1}$ at 20C. Cui et al. ${ }^{13}$ prepared an interconnected Si hollow nano sphere electrode displaying a discharge capacity of $1387 \mathrm{~mA} \mathrm{~h} \mathrm{~g}^{-1}$ at $14 \mathrm{~A} \mathrm{~g}^{-1}$, which is $57 \%$ of the capacity obtained at $0.44 \mathrm{~A} \mathrm{~g}^{-1}$. Wang et al. ${ }^{14}$ prepared the $\mathrm{Si} / \mathrm{C} / \mathrm{G}$ micro/ nanocomposite that could reach $470 \mathrm{~mA} \mathrm{~h} \mathrm{~g}^{-1}$ at $5 \mathrm{~A} \mathrm{~g}^{-1}$.

Herein, we designed a yolk-shell structure of carbon/ graphene double-layer coated-silicon material to alleviate the serious structure crush and promote the intrinsic low electrical conductivity of silicon nanoparticles. Specifically, the inner carbon coating could enhance the surface electronic conductivity of silicon nanoparticles, while the outer layer of graphene sheets, which act as flexible and conductive bridges, could not only enhance the intergranular conductivity among silicon particles, but also provide an effective buffer space for the volume expansion of silicon and maintain the integrity of the electrode structure. ${ }^{15}$

\section{Experimental}

\subsection{Materials}

Si particles (100-200 nm) were obtained from the Shenzhen Kejing Star Technology Co. China. Acetonitrile $\left(\mathrm{C}_{2} \mathrm{H}_{3} \mathrm{~N}\right)$ and 
glucose $\left(\mathrm{C}_{6} \mathrm{H}_{12} \mathrm{O}_{6}\right.$, the Sinopharm Chemical Reagent Co., Ltd) were used as received.

\subsection{Sample preparation}

2.2.1. Pretreatment of silicon particles. Nano-sized $\mathrm{Si}$ particles in stock could be oxidized and should be pretreated to remove the surface oxide layer. In the typical process of chemical etching, $2 \mathrm{~g}$ of $\mathrm{Si}$ particles was added to a solution of $200 \mathrm{ml}$ acetonitrile and $4 \mathrm{ml} \mathrm{HF} \mathrm{(w/w}=40 \%)$ was then stirred continuously at room temperature for $0.5 \mathrm{~h}$ to eliminate the oxide layer. The pretreated Si particles were collected and dried.

2.2.2. Preparation of carbon-coated silicon (Si/C) particles. The as-pretreated Si powders and glucose at a mass ratio of $10: 1$ were accurately weighed and grinded in an agate mortar. The mixed powders were transferred into a small amount of de- ionized water with vigorously stirring at $300 \mathrm{rpm}$ for $1 \mathrm{~h}$ to form a homogeneously mixed slurry, which was then heated up to $90{ }^{\circ} \mathrm{C}$ for $12 \mathrm{~h}$. The dried mixture was mashed and the resulting powders were finally put in a crucible for calcination in a nitrogen atmosphere at $600{ }^{\circ} \mathrm{C}\left(5^{\circ} \mathrm{C} \mathrm{min}^{-1}\right)$ for $6 \mathrm{~h}$ to form $\mathrm{Si}$ / C particles.

2.2.3. Preparation of graphene-coated silicon ( $\mathrm{Si} / \mathrm{G})$ particles. Graphene oxide (GO) sheets were first synthesized via a novel Hummers' approach from natural graphite flakes. Subsequently, a hydrothermal process was applied to synthesize the $\mathrm{Si} / \mathrm{G}$ composites. Typically, $1 \mathrm{~g}$ Si and $0.1 \mathrm{~g} \mathrm{GO}(\mathrm{w} / \mathrm{w}=10: 1)$ were dispersed in ethanol and ultrasonically treated for $0.5 \mathrm{~h}$ to form a suspension. The compound suspension was transferred into a $100 \mathrm{ml}$ PTFE-lined autoclave, and kept at $180^{\circ} \mathrm{C}$ for $12 \mathrm{~h}$ in the vacuum oven. Upon the completion of the reaction, the

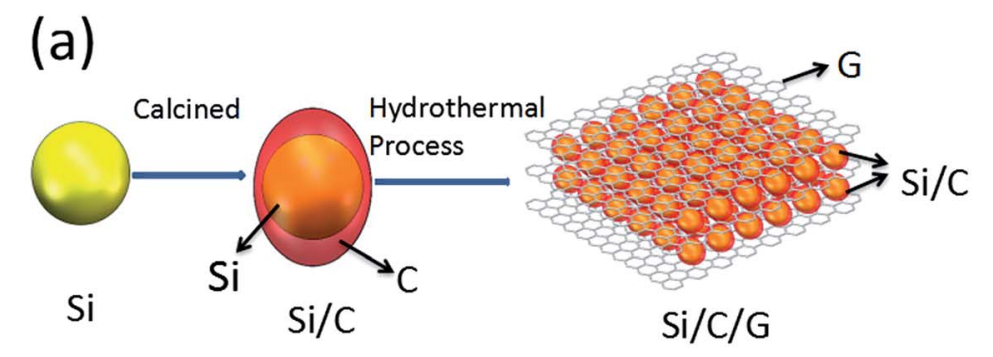

(b)

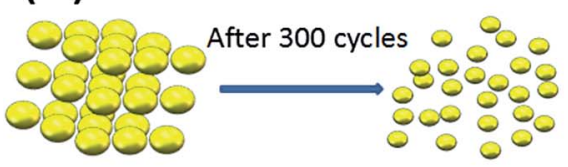

$\mathrm{Si}$

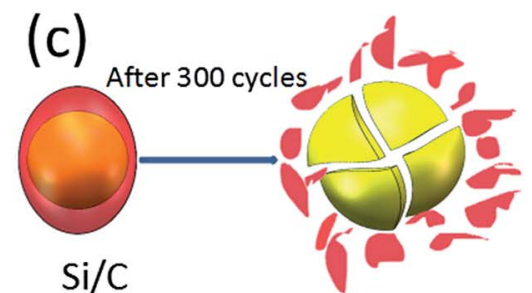

Fig. 1 (a) Schematics illustration of the synthesis of the Si/C/G, (b) and (c) shows Si, Si/C structure changes of after many cycles.

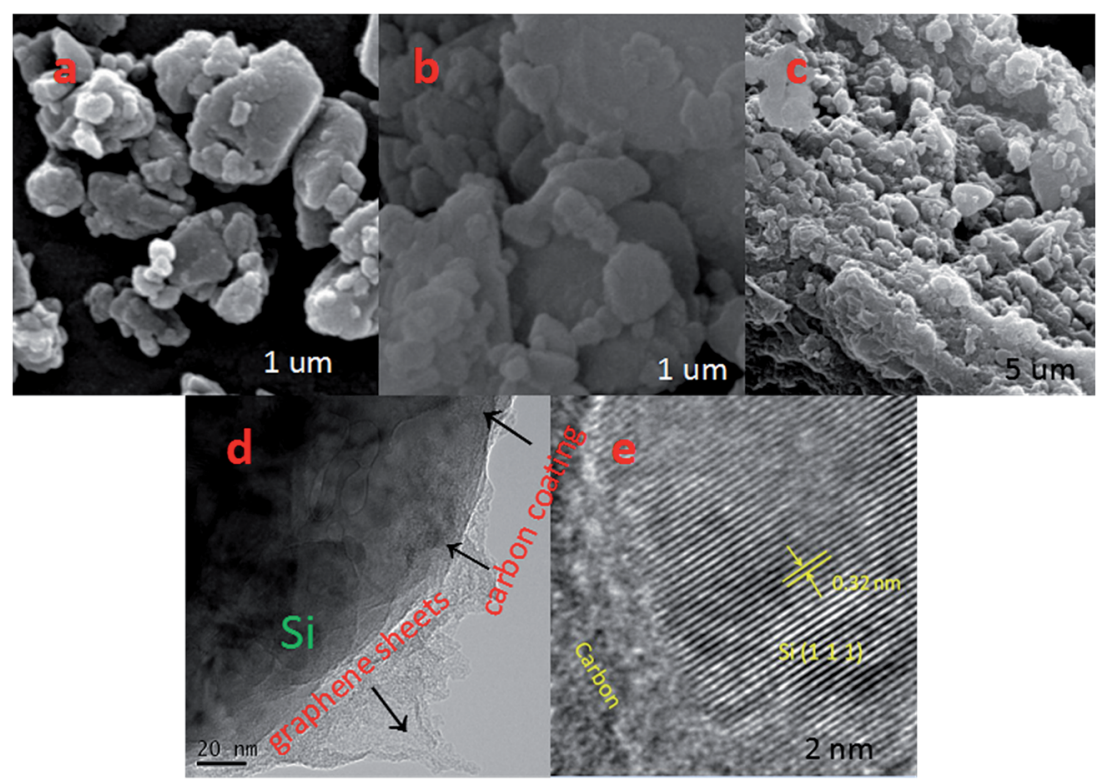

Fig. 2 SEM images of (a) Si, (b) Si/C and (c) Si/C/G electrodes. (d) TEM and (e) HRTEM images of the Si/C/G materials. 
autoclave underwent the natural cooling till room temperature. Afterwards, the suspension was transformed into a wet solid mixture in a refrigerator and followed by vacuum drying to obtain the final solid products.

2.2.4. Synthesis of $\mathrm{Si}$ core/carbon/graphene (Si/C/G) composites. $1 \mathrm{~g}$ Si/C $(\mathrm{w} / \mathrm{w}=10: 1)$ and $0.1 \mathrm{~g}$ GO were dispersed in ethanol and ultrasonically treated for $0.5 \mathrm{~h}$ to form a suspension. Afterwards, the same processes for the preparation of $\mathrm{Si} / \mathrm{G}$ composites was used to synthesize the $\mathrm{Si} / \mathrm{C} / \mathrm{G}(\mathrm{w} / \mathrm{w}=$ $10: 1: 1)$ composite.

\subsection{Sample characterization}

$\mathrm{Si} / \mathrm{C} / \mathrm{G}$ materials were characterized using X-ray diffraction (XRD, DX-1000) with $\mathrm{Cu}-\mathrm{K}_{\alpha}$ radiation. Field emission electron scanning microscope (SEM, JEOL JSM-5900LV) operated at 10 $\mathrm{KV}$ was used to observe the microstructure morphology and energy dispersive X-ray spectroscopy (EDX) was used to analyze the element mappings. TEM/HR-TEM images were taken on a JEOL JEM-2100F microscope. X-ray photoelectron spectroscopy (XPS) measurement was performed with a Kratos XSAM800 spectrometer using $\mathrm{Mg} \mathrm{K}_{\alpha 1,2}$ radiations.

\subsection{Electrochemical measurements}

The electrochemical performance of the $\mathrm{Si} / \mathrm{C} / \mathrm{G}$ material was evaluated in 2032-type coin cells. The $\mathrm{Si} / \mathrm{C} / \mathrm{G}$ composite sample was mixed with conductive carbon black and carboxyl methyl cellulose $(\mathrm{w} / \mathrm{w}=60: 20: 20)$ to form a homogenous slurry. $\mathrm{Ni}$ foam cleaned with $2.0 \mathrm{M} \mathrm{HCl}$ solution was used as the current collector. The working electrodes were prepared by pasting the slurry onto the as-prepared $\mathrm{Ni}$ foam, and drying at $80{ }^{\circ} \mathrm{C}$ under vacuum oven for $5 \mathrm{~h}$. Coin cells were assembled in an argonfilled glove box using lithium foil as the counter electrode, polypropylene film as the separator. The electrolyte was $1.0 \mathrm{M}$ $\mathrm{LiPF}_{6}$ in $1: 1 \mathrm{w} / \mathrm{w}$ ethylene carbonate/diethyl carbonate, with 1 volume\% fluoroethylene carbonate added to improve the cycling stability. The battery was assembled in the order of "the positive electrode shell - electrode sheet - electrolyte - diaphragm - electrolyte - lithium plate - steel sheet - spring plate -
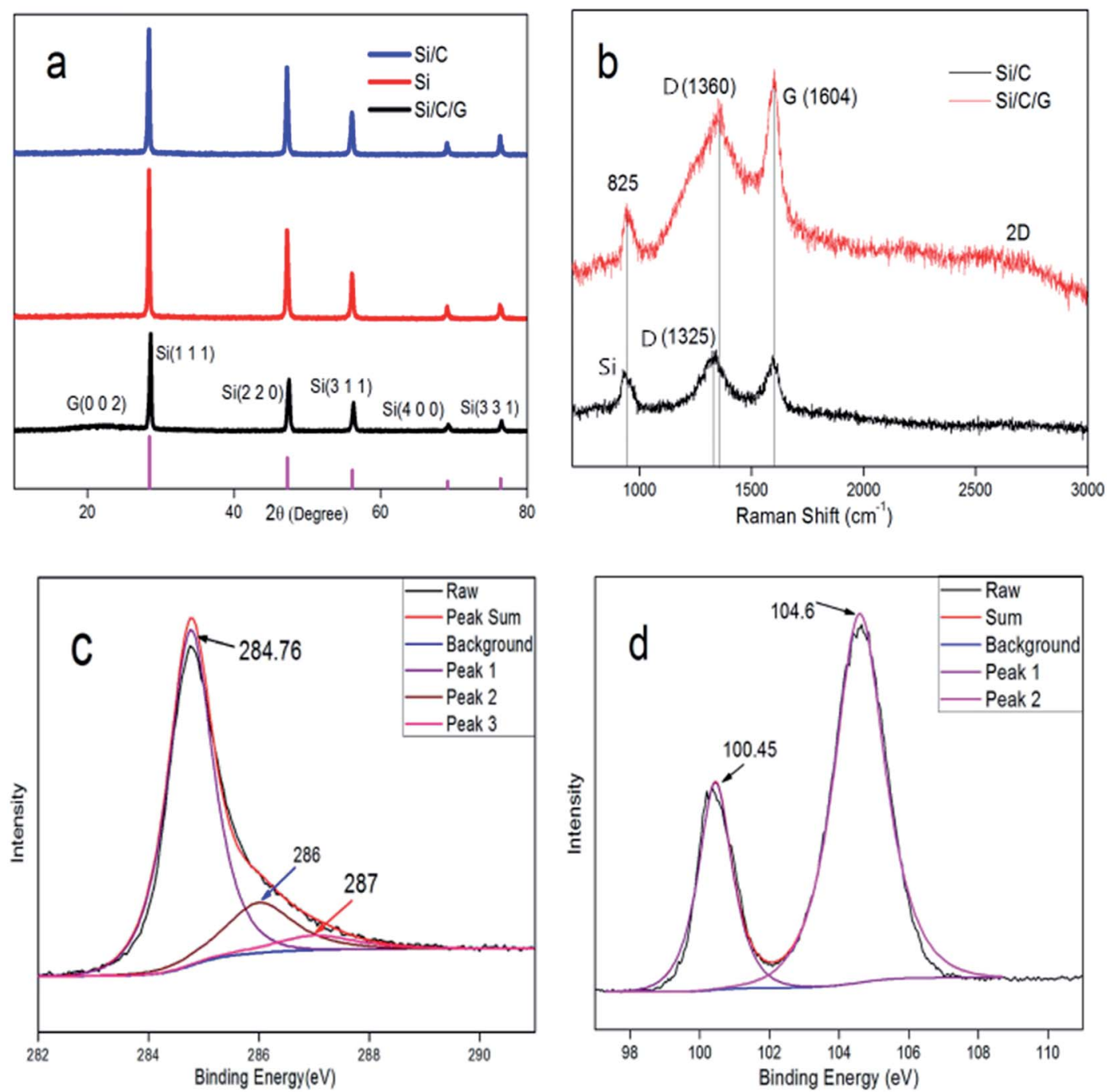

Fig. 3 (a) XRD patterns of Si, Si/C and Si/C/G composites. (b) Raman spectra of the Si/C and Si/C/G composites. The XPS spectra (c) C 1s and (d) Si $2 p$ of the $\mathrm{Si} / \mathrm{C} / \mathrm{G}$ composite. 
negative housing". All the cells were cycled between 0.01 and $3 \mathrm{~V}$ versus $\mathrm{Li} / \mathrm{Li}^{+}$. Specific capacity values were calculated based on the total mass of the $\mathrm{Si} / \mathrm{C} / \mathrm{G}$. The mass loading of active materials on the electrode was ranging from $0.6 \mathrm{mg}$ to $1 \mathrm{mg}$ (including $\mathrm{Si}, \mathrm{C}$ and $\mathrm{G}$ ).

\section{Results and discussion}

The schematic diagrams for the formation of Si/C/G materials are illustrated in Fig. 1a. Firstly, the pretreated Si nanoparticles and glucose were used as the starting material to prepare yolkshell structured $\mathrm{Si} / \mathrm{C}$ composite via a grinding/mixing and calcination process. The $\mathrm{Si} / \mathrm{C} / \mathrm{G}$ composite was further synthesized using $\mathrm{Si} / \mathrm{C}$ and $\mathrm{GO}$ powders through a hydrothermal process. Fig. $2 \mathrm{a}-\mathrm{c}$ shows the typical SEM image of $\mathrm{Si}, \mathrm{Si} / \mathrm{C}, \mathrm{Si} / \mathrm{C} /$ G composites, respectively. Obviously, there are many differences in morphology and brightly colored surfaced of the conductive $\mathrm{Si} / \mathrm{C} / \mathrm{G}$ show better. Fig. $2 \mathrm{~d}$ shows the typical of TEM image, which clearly discloses that core-shell structure of Si/C/ G material. High resolution TEM in Fig. 2e also confirms the highly crystalline characteristic of the Si nanoparticles, with a $d$ spacing of $0.32 \mathrm{~nm}$.

The structure of the prepared $\mathrm{Si} / \mathrm{C} / \mathrm{G}$ material was analyzed by X-ray diffraction (DX-1000). Fig. 3a presents the XRD patterns of the $\mathrm{Si}, \mathrm{Si} / \mathrm{C}$ and $\mathrm{Si} / \mathrm{C} / \mathrm{G}$ composites. In the XRD pattern of the as-obtained $\mathrm{Si} / \mathrm{C} / \mathrm{G}$ composite, the main diffraction peaks at $28.4^{\circ}, 47.24^{\circ}, 56.06^{\circ}, 69.08^{\circ}$ and $76.28^{\circ}$ can be indexed as the $(1$

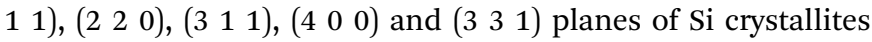
(JCPDS no. 27-1402), respectively. Compared with $\mathrm{Si}$ and Si/C, there are diffraction peaks at $23.48^{\circ}$ with $\mathrm{Si} / \mathrm{C} / \mathrm{G}$ composite, indicating the carbon derived from the graphene oxide. Fig. $3 \mathrm{~b}$ presents the Raman spectra of the $\mathrm{Si} / \mathrm{C} / \mathrm{G}$ composites. In the two spectra, the band located at $825 \mathrm{~cm}^{-1}$ corresponds to the crystalline $\mathrm{Si}$, demonstrating the existence of active Si materials in all the obtained composites. In the Raman spectra of two composites, the characteristic peaks at around $\mathrm{D}\left(1360 \mathrm{~cm}^{-1}\right)$ and $\mathrm{G}$ Bands $\left(1604 \mathrm{~cm}^{-1}\right)$ are known to depend on the structural nature of carbon. In contrast to $\mathrm{Si} / \mathrm{C}$ composite, the bonds at about $2600 \mathrm{~cm}^{-1}$ relevant to the $2 \mathrm{D}$ peak of Si/C/G composite, which indicates the existence of graphitized carbon and multilayer structure. ${ }^{14,16-18}$ While the intensity ratio of $\mathrm{D} / \mathrm{G}$ band is not very high, demonstrating few defects and excellent quality of $\mathrm{rGO}$, in favor of applications in LIBs.

Fig. 3c presents the high-resolution X-ray photoelectron spectroscopy (XPS) spectra of C 1s with synthesized Si/C/G composite, illustrating the existence of three types of bonding forms for the carbon atoms in the $\mathrm{Si} / \mathrm{C} / \mathrm{G}$ composite. The observed peak at $284.7 \mathrm{eV}$ should be corresponding to the carbon atoms in the chemical bonds of $\mathrm{C}-\mathrm{C}$. The other two peaks at $286 \mathrm{eV}$ and $287 \mathrm{eV}$ correspond that the carbon atoms in the functional groups of C-OR and COOR, individually. Three types of peaks came from two carbonaceous materials including graphitized carbon of graphene and amorphous carbon in glucose. Fig. 3d presents the XPS spectra of Si 2p. The peak at $100.45 \mathrm{eV}$ and $104.6 \mathrm{eV}$ is attributed to silicon powders and the silicon oxides, which indicates the $\mathrm{Si} / \mathrm{C} / \mathrm{G}$ composite was partially oxidized during the process of grinding slurry in the air. $^{14}$

The elemental component in the $\mathrm{Si} / \mathrm{C} / \mathrm{G}$ composite is construed by the energy dispersive X-ray spectroscopy as well as the elemental mappings. Fig. $4 \mathrm{~b}$ and $\mathrm{d}$ further demonstrates that the active $\mathrm{Si}$ and $\mathrm{C}$ elements are uniformly distributed in the $\mathrm{Si} / \mathrm{C} / \mathrm{G}$ microspheres. Fig. $4 \mathrm{c}$ reveals that the $\mathrm{O}$ element scatters homogeneously in the whole material, indicating that the $\mathrm{O}$ element should be originated from the absorbed oxygen on the surface of material. ${ }^{1,6,14}$

In behalf of highlight the preferable performance of $\mathrm{Si} / \mathrm{C} / \mathrm{G}$ compound for anode application in LIBs, we made all the four materials of batteries to compare it are electrochemical performance. ${ }^{19}$ Cyclic Voltammograms (CV) of the electrodes based on the $\mathrm{Si} / \mathrm{C} / \mathrm{G}$ composites were measured in the potential window from 0.01 to $1.5 \mathrm{~V}\left(v s . \mathrm{Li} / \mathrm{Li}^{+}\right)$at a scan rate of $0.5 \mathrm{mV} \mathrm{s}^{-1}$, as shown in Fig. 5a. In the first catholic half-cycle (lithiation), an extend catholic peak was inspected at about $0.82 \mathrm{~V}$, which was generally associated with the formation of the solid electrolyte interface (SEI) layer in the process of the reaction of $\mathrm{Li}^{+}$with the electrolyte. The other two anode peaks around $0.35 \mathrm{~V}$ and $0.59 \mathrm{~V}$ are relevant to the decomposition of the $\mathrm{Li}-\mathrm{Si}$ phases. To further investigate the cycling stability of $\mathrm{Si} / \mathrm{C} / \mathrm{G}$ composite used as electrodes of LIBs, we compared the electrochemical impedance spectroscopy (EIS) of $\mathrm{Si}, \mathrm{Si} / \mathrm{C}, \mathrm{Si} / \mathrm{G}$ and $\mathrm{Si} / \mathrm{C} / \mathrm{G}$ composites, respectively. Fig. $5 \mathrm{~b}$ presents the Nyquist plots of all the four composite electrodes at the charge/discharge states. The depressed semicircles in the high frequency region represent the overlap of the resistance of the SEI film and the chargetransfer resistance, while the straight lines in the low frequency region correspond to the diffusion of lithium ions. ${ }^{20}$ The Si anode has clearly the largest charge-transfer resistance (RCT) among the four samples. Strikingly, the RCT of the Si/C

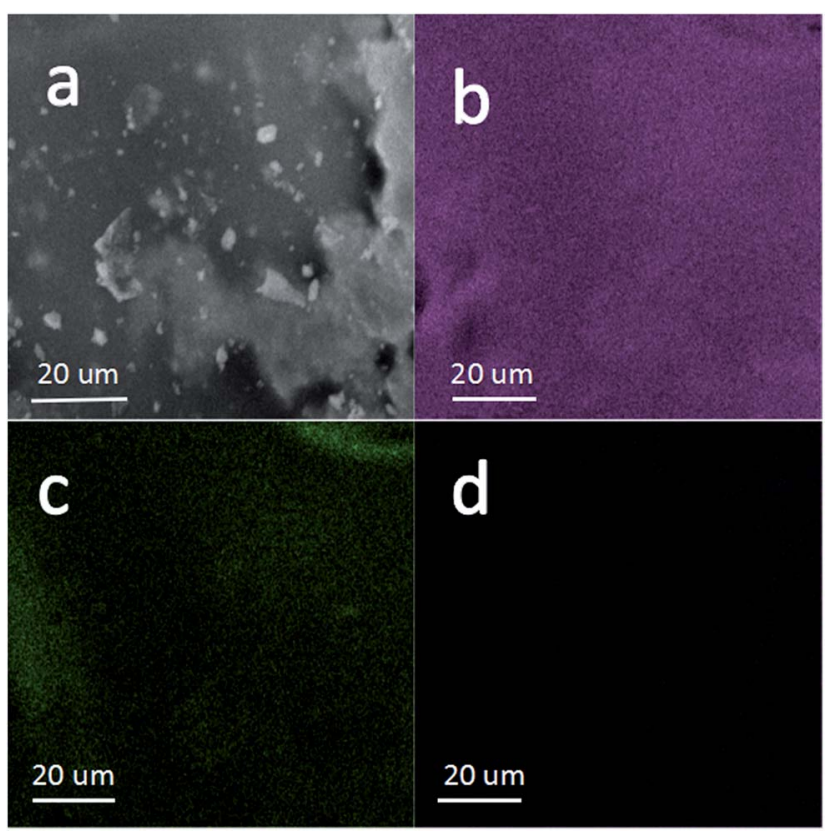

Fig. 4 (a) Magnified SEM image and mapping results of (b) Si (purple), (c) $\bigcirc$ (green), (d) C (L T magenta) of the Si/C/G composite. 

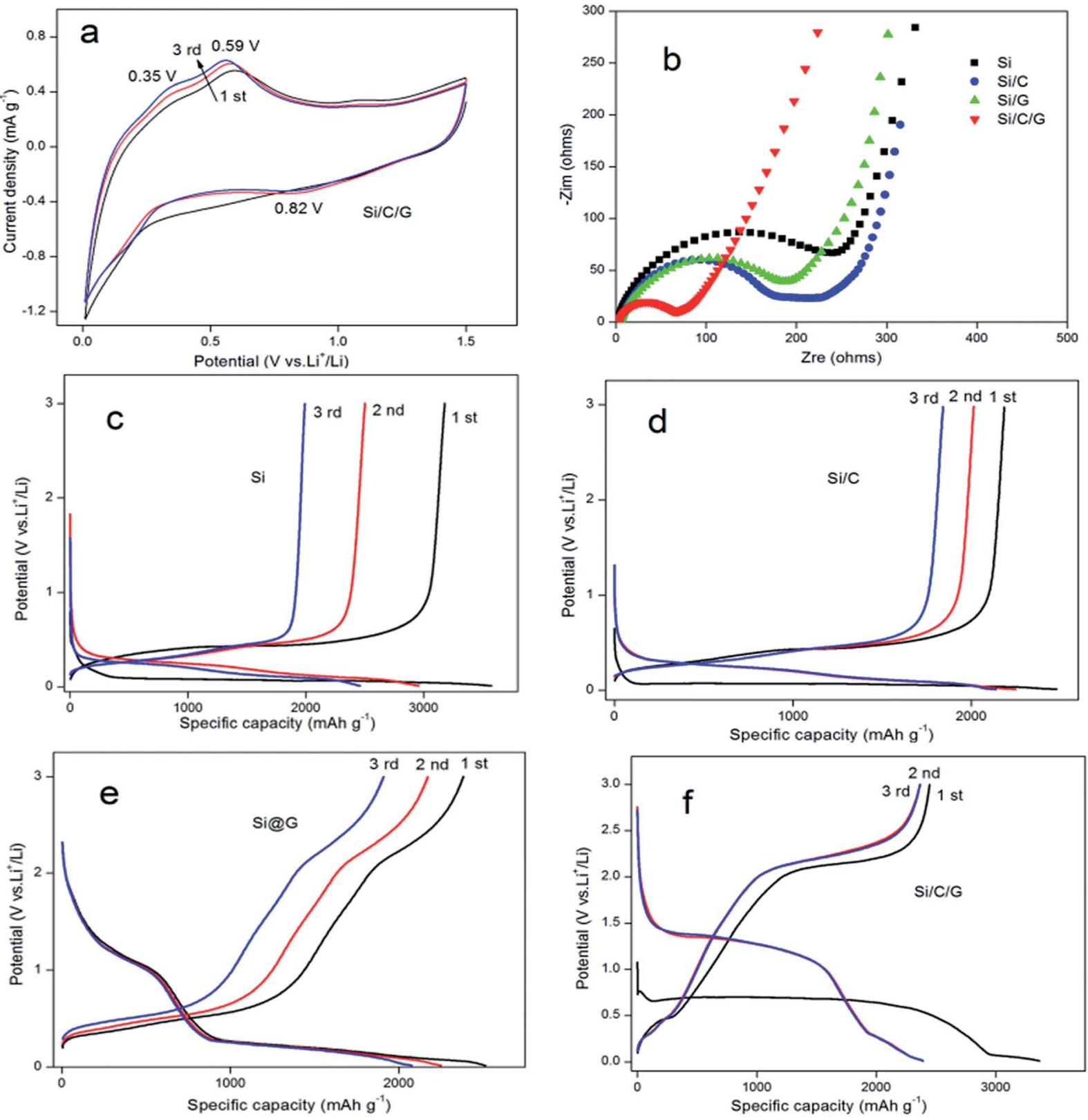

Fig. 5 (a) Cycling performance of the Si/C/G composite from 0.01 to $1.5 \mathrm{~V}$ at a scanning rate of $0.5 \mathrm{mV} \mathrm{s}^{-1}$. (b) Nyquist plots of the pristine Si, Si/ C, Si/G and Si/C/G composites. (c)-(f) First three discharge/charge behaviors of the $\mathrm{Si}, \mathrm{Si} / \mathrm{C}, \mathrm{Si} / \mathrm{G}$ and Si/C/G composites at a current density of $0.2 \mathrm{~A} \mathrm{~g}^{-1}$.

and $\mathrm{Si} / \mathrm{G}$ are relatively small, demonstrating that carbon is helpful to the electron transfer. Evidently, the diameter of the semicircle of the $\mathrm{Si} / \mathrm{C} / \mathrm{G}$ composite electrode is the smallest in the four electrodes, illustrating that amorphous carbon layer and graphene sheets could further enhance the conductivity. ${ }^{21}$ Fig. 5c-f show the testing curves obtained from the LIBs with a $\mathrm{Si}, \mathrm{Si} / \mathrm{C}, \mathrm{Si} / \mathrm{G}$ and $\mathrm{Si} / \mathrm{C} / \mathrm{G}$ at a current density $0.2 \mathrm{~A} \mathrm{~g}^{-1}$ with a voltage ranging from $0.01 \mathrm{~V}$ to $3 \mathrm{~V}$, which can conclude that the deep lithiation and delithiation for the first three cycles. ${ }^{22,23}$ The Si electrode exhibits a reversible discharge specific capacity up to $3575 \mathrm{~mA} \mathrm{~h} \mathrm{~g}^{-1}$ for the first cycle, which shows beneficially eliminated volume variations and pulverization of active material after coating carbon. Practically, compared with Si and
Si/C composites, discharge and charge platforms apparently rise in $\mathrm{Si} / \mathrm{G}, \mathrm{Si} / \mathrm{C} / \mathrm{G}$ composites, indicating that graphene promoted the ionic conductivity and decreased internal resistance of silicon electrode. Therefore, $\mathrm{Si} / \mathrm{C} / \mathrm{G}$ composite structure presented prominent status for preparation in LIBs with superior cycling stability. In the other hand, the columbic efficiency was found to be almost $100 \%$ (reference Fig. 6b) since the second cycle, suggesting the better reversibility of $\mathrm{Si} / \mathrm{C} / \mathrm{G}$ electrodes compared with the previously reported. The irreversible discharge specific capacity for the first charge is owing to the formation of the SEI layer on the surface of $\mathrm{Si} / \mathrm{C} / \mathrm{G}$ electrodes. ${ }^{9,14,24}$ Moreover, Fig. $5 \mathrm{f}$ also shows a stable charge plateau 

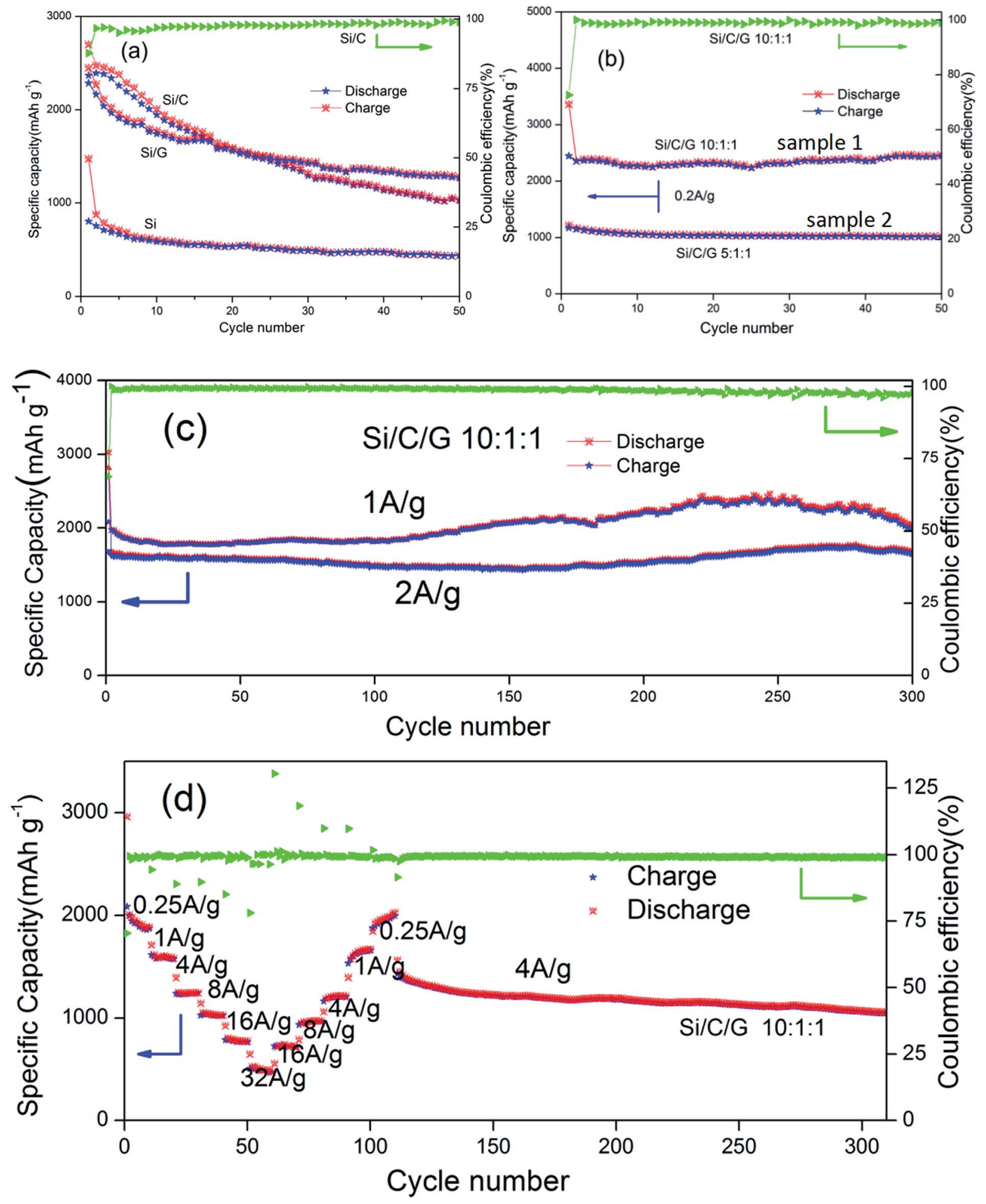

Fig. 6 (a) Cycling performance and specific capacity of Si, Si/C and Si/G composite electrodes. (b) The comparisons of cycling stability and specific capacity of $\mathrm{Si} / \mathrm{C} / \mathrm{G}$ composites with different mass ratio. (c) Discharge capacity and coulombic efficiency of the Si/C/G composite electrode at current density of 1 and $2 \mathrm{~A} \mathrm{~g}^{-1}$. (d) Rate performance for the Si/C/G composites electrode at different charge/discharge current densities ranging from $0.25 \mathrm{~A} \mathrm{~g}^{-1}$ to $32 \mathrm{~A} \mathrm{~g}^{-1}$.

at $2.4 \mathrm{~V}$ from the first to the 3rd cycle, indicating an excellent cycling stability of the $\mathrm{Si} / \mathrm{C} / \mathrm{G}$ composite. ${ }^{25-27}$

Fig. 6a shows the cycling behavior and specific capacity of the pure $\mathrm{Si}, \mathrm{Si} / \mathrm{C}$ and $\mathrm{Si} / \mathrm{G}$ in coin-type half cells. The specific capacity of pure was the lowest in all the composites. The initial discharge specific capacities (at $0.2 \mathrm{~A} \mathrm{~g}^{-1}$ ) of the $\mathrm{Si} / \mathrm{C}, \mathrm{Si} / \mathrm{G}$ composites and Si are about 2699, 2515 and $1476 \mathrm{~mA} \mathrm{~h} \mathrm{~g}^{-1}$, respectively. After 50 cycles, it still retains 1039, 1253 and 
$442 \mathrm{~mA} \mathrm{~h} \mathrm{~g}{ }^{-1}$, individually, all of which are apparently higher than the pure $\mathrm{Si}^{\mathbf{1 4 , 2 8 - 3 0}}$ Fig. $6 \mathrm{~b}$ compares the cycling stability and specific capacity $\left(0.2 \mathrm{~A} \mathrm{~g}^{-1}\right)$ of $\mathrm{Si} / \mathrm{C} / \mathrm{G}$ composites with different mass ratio. The initial discharge specific capacities for samples (10:1:1, $5: 1: 1$ ) are 3366, $1215 \mathrm{~mA} \mathrm{~h} \mathrm{~g}^{-1}$, and after 50 cycle, it still retains $2469,1024 \mathrm{~mA} \mathrm{~h} \mathrm{~g}^{-1}$, respectively. On the contrast, the cycling stability and discharge specific capacity of simple (1) is clearly surpassed (2) at the same current density. ${ }^{31}$ The sample (2) shows excellent cycle stability but low discharge specific capacity, the reason of which could owning to too much carbon, ${ }^{32-34}$ while the sample (1) displays a better performance. Furthermore, the previously reported $\mathrm{Si} / \mathrm{C}$ composite microspheres with hierarchical core-shell structure as anode for lithium ion batteries showed a capacity about $900 \mathrm{~mA} \mathrm{~h} \mathrm{~g}{ }^{-1}$ at $0.2 \mathrm{~A} \mathrm{~g}^{-1}$ after 50 cycles. In present work, the discharge specific capacity of $\mathrm{Si} / \mathrm{C} / \mathrm{G}$ composite above $2300 \mathrm{~mA} \mathrm{~h} \mathrm{~g}^{-1}$ under the same conditions. ${ }^{14,21}$ Fig. $6 \mathrm{c}$ shows a long cycle performance (300 cycles) at different discharging currents of $1 \mathrm{~A} \mathrm{~g}^{-1}, 2 \mathrm{~A} \mathrm{~g}^{-1}$, which shows stable capacities around $2000,1600 \mathrm{~mA} \mathrm{~h} \mathrm{~g}$ respectively. Capacity degradation is almost negligible in this case, demonstrating good stability of the $\mathrm{Si} / \mathrm{C} / \mathrm{G}$ composites. ${ }^{33,35}$ As previously reported, dual-carbon enhanced silicon-based composite showed a capacity around $800 \mathrm{~mA} \mathrm{~h} \mathrm{~g} \mathrm{~g}^{-1}$ at $0.5 \mathrm{~A} \mathrm{~g}^{-1}$ for 150 cycles, and with a capacity retention of $90 \%$ after 150 cycles. By contrast, we have prepared uncomplicated $\mathrm{Si} / \mathrm{C} / \mathrm{G}$ composites which still maintained discharge specific capacity above $2000 \mathrm{~mA} \mathrm{~h} \mathrm{~g}{ }^{-1}$ after 300 cycles. $^{36,37}$ The rate property was measured from 0.25 to $32 \mathrm{~A} \mathrm{~g}^{-1}$ and again $0.25 \mathrm{~A} \mathrm{~g}^{-1}$, followed by cycling at $4 \mathrm{~A} \mathrm{~g}^{-1}$ for additional 210 cycles. ${ }^{38-40}$ As shown in Fig. 6d, the $\mathrm{Si} / \mathrm{C} / \mathrm{G}$ anode exhibited a superior moderate rate capability, with a capacity of $500 \mathrm{~mA} \mathrm{~h} \mathrm{~g}^{-1}$ at $32 \mathrm{~A} \mathrm{~g}^{-1}$, about $40 \%$ of its capacity at $0.25 \mathrm{~A} \mathrm{~g}^{-1}$. After the rate performance test, the coin cell was cycled for additional 210 cycles at $4 \mathrm{~A} \mathrm{~g}^{-1}$, maintaining $1057 \mathrm{~mA} \mathrm{~h} \mathrm{~g}^{-1}$ and $80 \%$ of its reversible capacity, which further confirms the excellent cycling and rate performance of $\mathrm{Si} / \mathrm{C} / \mathrm{G}$ anodes. ${ }^{\mathbf{4 1 , 4 2}}$

The morphological changes of the $\mathrm{Si} / \mathrm{C} / \mathrm{G}$ electrode in the process of lithiation-delithiation are characterized by SEM and the results are shown in Fig. 7. Fig. 7a and b show the initial morphologies of the $\mathrm{Si} / \mathrm{C} / \mathrm{G}$ electrode before charge/discharge cycling, and after 700 cycles, respectively. It can be seen that both images display a similar morphology of the $\mathrm{Si} / \mathrm{C} / \mathrm{G}$ composite. Even after long-time cycling, the $\mathrm{Si} / \mathrm{C} / \mathrm{G}$ composite particles are still closely packed and uniformly distributed on

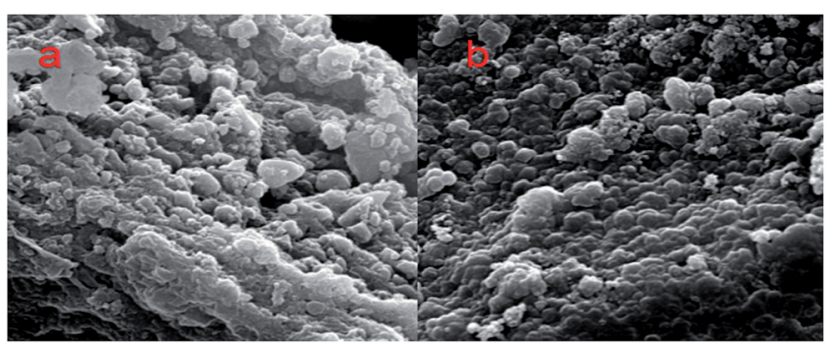

Fig. 7 (a) and (b) SEM images of Si/C/G electrodes before and after 700 cycles. the current collector, without showing fractures or cracking. Moreover, although silicon experiences great volume deformation during lithiation/delithiation process, no apparent changes in particle size are observed in the $\mathrm{Si} / \mathrm{C} / \mathrm{G}$ material after cycling, indicating the extraordinary structural stability of our sample.

Herein, we develop a simple approach using double carbon coated nano-sized $\mathrm{Si}$ as the anode material. As the anode, carbon-coated nano-sized $\mathrm{Si}$ composites can significantly improve the cycle performance and enhance specific capacity, while it falls short of achieving the desired commercial goals. To boost batteries rate performance and cycling behavior, we develop a facile hydrothermal route to readily form a hybrid structure of $\mathrm{Si} /$ carbon/graphene bilayers ( $\mathrm{Si} / \mathrm{C} / \mathrm{G}$ ). Especially, superior rate performance of the resulting composites could perfectly meet the commercial demand for the rapid charge and discharge.

\section{Conclusions}

We have successfully synthesized $\mathrm{Si} / \mathrm{C} / \mathrm{G}$ nanocomposite material via two-step chemical reaction of silicon particles. To improve the specific capacity, cycle and rate performance of nanometer-sized silicon particles, the amorphous carbon was coated on the Si surface to form more steady core-shell structure. Furthermore, the core-shell structure was surrounded by graphene via a simple hydrothermal process, which preserves the integrity of silicon particles. The $\mathrm{Si} / \mathrm{C} / \mathrm{G}$ composite dramatically buffered the volume expansion and enhanced the ion conductivity, which maintained the high specific capacity while promoted the cycle stability and rate performance. From electrochemical performance analysis, the $\mathrm{Si} / \mathrm{C} / \mathrm{G}$ composite remarkably ameliorate the rate performance of Si-based anode material and promote their development of practical application in high performance lithium ion batteries.

\section{Conflicts of interest}

There are no conflicts to declare.

\section{Acknowledgements}

Financial support provided by the Sichuan Science and Technology through (2015GZ0130, 2015GZ0132, 2016GZ0025) is gratefully acknowledged.

\section{References}

1 X. Huang, J. Yang, S. Mao, J. Chang, P. B. Hallac, C. R. Fell, B. Metz, J. Jiang, P. T. Hurley and J. Chen, Adv. Mater., 2014, 26, 4326-4332.

2 M. Ge, J. Rong, X. Fang and C. Zhou, Nano Lett., 2012, 12, 2318-2323.

3 D.-H. Liu, H.-Y. Lü, X.-L. Wu, J. Wang, X. Yan, J.-P. Zhang, H. Geng, Y. Zhang and Q. Yan, Nanoscale Horiz., 2016, 1, 496-501. 
4 S. Maskova, K. Miliyanchuk, L. Akselrud, I. Halevy, M. Giovannini and L. Havela, J. Alloys Compd., 2017, 694, 201-207.

5 T. Song, J. Xia, J. H. Lee, D. H. Lee, M. S. Kwon, J. M. Choi, J. Wu, S. K. Doo, H. Chang, W. I. Park, D. S. Zang, H. Kim, Y. Huang, K. C. Hwang, J. A. Rogers and U. Paik, Nano Lett., 2010, 10, 1710-1716.

6 J. K. Yoo, J. Kim, H. Lee, J. Choi, M. J. Choi, D. M. Sim, Y. S. Jung and K. Kang, Nanotechnology, 2013, 24, 424008.

7 J. Xie, G. Wang, Y. Huo, S. Zhang, G. Cao and X. Zhao, Electrochim. Acta, 2014, 135, 94-100.

8 M.-S. Wang, L.-Z. Fan, M. Huang, J. Li and X. Qu, J. Power Sources, 2012, 219, 29-35.

9 H. Park, S. Lee, S. Yoo, M. Shin, J. Kim, M. Chun, N. S. Choi and S. Park, ACS Appl. Mater. Interfaces, 2014, 6, 1636016367.

10 S. Li, X. Qin, H. Zhang, J. Wu, Y.-B. He, B. Li and F. Kang, Electrochem. Commun., 2014, 49, 98-102.

11 J.-Z. Guo, X.-L. Wu, F. Wan, J. Wang, X.-H. Zhang and R.-S. Wang, Chem.-Eur. J., 2015, 21, 17371-17378.

12 H. Wu, G. Chan, J. W. Choi, I. Ryu, Y. Yao, M. T. McDowell, S. W. Lee, A. Jackson, Y. Yang, L. Hu and Y. Cui, Nat. Nanotechnol., 2012, 7, 310-315.

13 Y. Yao, M. T. McDowell, I. Ryu, H. Wu, N. Liu, L. Hu, W. D. Nix and Y. Cui, Nano Lett., 2011, 11, 2949-2954.

14 J. Wang, D.-H. Liu, Y.-Y. Wang, B.-H. Hou, J.-P. Zhang, R.-S. Wang and X.-L. Wu, J. Power Sources, 2016, 307, 738745.

15 D.-H. Liu, H.-Y. Lü, X.-L. Wu, B.-H. Hou, F. Wan, S.-D. Bao, Q. Yan, H.-M. Xie and R.-S. Wang, J. Mater. Chem. A, 2015, 3, 19738-19746.

16 A. K. Arora, M. Rajalakshmi, T. R. Ravindran and V. Sivasubramanian, J. Raman Spectrosc., 2007, 38, 604-617.

17 J. Chang, X. Huang, G. Zhou, S. Cui, P. B. Hallac, J. Jiang, P. T. Hurley and J. Chen, Adv. Mater., 2014, 26, 758-764.

$18 \mathrm{X} . \mathrm{Xu}, \mathrm{H}$. Zhang, Y. Chen, N. Li, Y. Li and L. Liu, J. Alloys Compd., 2016, 677, 237-244.

19 H.-Y. Lü, F. Wan, L.-H. Jiang, G. Wang and X.-L. Wu, Part. Part. Syst. Charact., 2016, 33, 204-211.

20 M.-S. Wang, Y. Song, W.-L. Song and L.-Z. Fan, ChemElectroChem, 2014, 1, 2124-2130.

21 W. Sun, R. Hu, M. Zhang, J. Liu and M. Zhu, J. Power Sources, 2016, 318, 113-120.

22 R. Dai, W. Sun, L. P. Lv, M. Wu, H. Liu, G. Wang and Y. Wang, Small, 2017, 13, 1003-1007.
23 U. Kasavajjula, C. Wang and A. J. Appleby, J. Power Sources, 2007, 163, 1003-1039.

24 N. Liu, Z. Lu, J. Zhao, M. T. McDowell, H. W. Lee, W. Zhao and Y. Cui, Nat. Nanotechnol., 2014, 9, 187-192.

25 S. Wang, J. Liao, M. Wu, Z. Xu, F. Gong, C. Chen, Y. Wang and X. Yan, Part. Part. Syst. Charact., 2017, 1700141, DOI: 10.1002/ppsc.201700141.

26 Q. Pan, P. Zuo, S. Lou, T. Mu, C. Du, X. Cheng, Y. Ma, Y. Gao and G. Yin, J. Alloys Compd., 2017, 723, 434-440.

27 X. L. Bin Wang, X. Zhang, B. Luo, M. Jin, M. Liang, S. A. Dayeh, L. Zhi and S. T. Picraux, ACS Nano, 2013, 7, 6467-6472.

28 B. Wang, X. Li, X. Zhang, B. Luo, Y. Zhang and L. Zhi, Adv. Mater., 2013, 25, 3560-3565.

29 N. Liu, H. Wu, M. T. McDowell, Y. Yao, C. Wang and Y. Cui, Nano Lett., 2012, 12, 3315-3321.

30 W. Jiang, M. Wu, F. Liu, J. Yang and T. Feng, $R S C A d v ., 2017$, 7, 44296-44302.

31 L. F. Cui, Y. Yang, C. M. Hsu and Y. Cui, Nano Lett., 2009, 9, 3370-3374.

32 Y. Xu, Y. Zhu, F. Han, C. Luo and C. Wang, Adv. Energy Mater., 2015, 5, 1400753.

33 Z. Lu, N. Liu, H.-W. Lee, J. Zhao, W. Li, Y. Li and Y. Cui, ACS Nano, 2014, 2540-2547.

34 K. Fu, O. Yildiz, H. Bhanushali, Y. Wang, K. Stano, L. Xue, X. Zhang and P. D. Bradford, Adv. Mater., 2013, 25, 51095114 .

35 D. A. Agyeman, K. Song, G.-H. Lee, M. Park and Y.-M. Kang, Adv. Energy Mater., 2016, 6, 1600904.

36 S. Ohara, J. Suzuki, K. Sekine and T. Takamura, J. Power Sources, 2004, 136, 303-306.

37 J. K. Lee, K. B. Smith, C. M. Hayner and H. H. Kung, Chem. Commun., 2010, 46, 2025-2027.

38 G. Derrien, J. Hassoun, S. Panero and B. Scrosati, Adv. Mater., 2007, 19, 2336-2340.

39 X. Zhao, C. M. Hayner, M. C. Kung and H. H. Kung, Adv. Energy Mater., 2011, 1, 1079-1084.

40 C. M. Park, J. H. Kim, H. Kim and H. J. Sohn, Chem. Soc. Rev., 2010, 39, 3115-3141.

41 B.-H. Hou, X.-L. Wu, Y.-Y. Wang, H.-Y. Lü, D.-H. Liu, H.-Z. Sun, J.-P. Zhang and H.-Y. Guan, Part. Part. Syst. Charact., 2015, 32, 1020-1027.

42 X.-L. Wu, Y.-G. Guo, J. Su, J.-W. Xiong, Y.-L. Zhang and L.-J. Wan, Adv. Energy Mater., 2013, 3, 1155-1160. 